\title{
Estate Tax Reforms in Taiwan: A Simulation Approach
}

\author{
Chiung-Ju Huang, Yuan-Hong Ho \\ Feng Chia University, Taichung, Taiwan
}

\begin{abstract}
This study uses the new classical Ramsey growth model to analyze the impacts of lowered estate tax rates in Taiwan. Simulation results indicate a decrease in capital stock and economic growth when post-adjusted estate tax rate falls below $28.22 \%$, which resembles the optimal estate tax rate to keep capital stock unchanged. The results also show that estate tax rate cuts have caused changes in relative prices, resulting in excess burden (EB). The implication of our simulation results is that Taiwan's current estate tax rate cut to $10 \%$ will not be able to increase capital stock and promote economic growth.
\end{abstract}

Keywords: capital stock, estate tax, excess burden (EB), tax neutrality

\section{Introduction}

Taiwan's estate taxes are levied for the purpose of redistributing income and wealth. However, the fairness and reasonableness of estate taxes have long been disputed, and many in the business community have publicly advocated abolishing estate taxes altogether in order to attract back investment funds from abroad.

Taiwan's estate tax is based on all property transferred at death. Taiwan's estate tax rate used to be progressive up to $50 \%$. The Ministry of Finance statistics show that at most only $2 \%$ of the national tax revenues were collected from estate tax, since many wealthy Taiwanese shift their money offshore, particularly to low-tax countries like Hong Kong and Singapore. From this, we can infer that the design of the estate tax, the collection of information on the object of the tax, and its tax collection methodology are far from perfect. But beyond that, an important factor for the inability to raise the share of tax revenue from estate tax lies in the loss of the tax base and the inability to expand it. To address this, the Ministry of Finance has proposed the introduction of a uniform tax rate of $10 \%$. In addition, the estate tax exemption will be increased to NT\$12,000,000 (US\$380,000) from the current NT\$7,800,000. It is worth noting that, in addition to the efficiency consideration, estate tax reform in Taiwan virtually has no justice at all. If the rich properly plan before death and evade taxes through a tax-efficient way of donation, estate tax reform of Taiwan will become a source of anti-social injustice. Therefore, in order to pursue economic development, fulfill social justice, and raise international competitiveness, the role of estate tax in modern economic economy is worth revisiting.

Looking at the tax systems of comparable tax jurisdictions in Asia, we find that Hong Kong scrapped its inheritance tax in February 2006; while Singapore divides its estate taxes into two rate brackets: 5\% for up to 20 million Singapore dollars and 10\% beyond that. The governments of Hong Kong and Singapore use low tax rates or tax exemption purposely to attract international capital inflows, stimulate financial activity,

Chiung-Ju Huang, associate professor, Department of Public Finance, Feng Chia University. Email: cjhuang@mail.fcu.edu.tw. Yuan-Hong Ho, professor, Department of Public Finance, Feng Chia University. 
and promote economic development and prosperity. In fact, overall tax revenues tend to increase after tax reductions and exemptions are offered. In Taiwan, where the government cut the capital gains tax on land by 50\%, the result was that land tax revenue increased from 2002 to 2004. This shows that large-scale cuts in tax rates need not lead to less revenue collection. If tax cuts are complemented by a set of supportive measures that promote the development of economic activity, an overall increase in tax revenues can be expected.

Until now, estate taxes and their effect on the aggregate economy remains a relatively neglected area in terms of economic research. Stiglitz (1978) showed that because of capital accumulation effects, the estate tax may increase the inequality of income and wealth. Kotlikoff and Summers (1981) suggested that intergenerational transfers are the primary source of aggregate capital accumulation. Bernheim (1987) argued that the indirect effects of estate taxes on personal income tax collections may offset the revenues generated by these transfer taxes. Munnell and Ernsberger (1988) found that revenues generated by estate taxes are nearly outweighed by their compliance costs. Wagner (1993) and Foster and Fleenor (1994) suggested that estate taxes depress business growth and investment. Astrachan and Tutterow (1996) conducted a survey of 1,003 US businesses and suggested that estate taxes may distort the investment and employment decisions of family businesses in ways that slow growth. In particular, this survey suggests that the prospect of estate taxes encourages a myopic investment policy and discourages firms from investing in projects where entrepreneurial risks are present.

Laitner (2001) believed that the abolition of estate tax will lead to more inequality in wealth distribution. Poterba and Weisbenner (2001) pointed out that because the US income taxes did not levy unrealized capital gains from inheritance, estate tax has prevented tax evasion and avoided the uneven income distribution function.

Holtz-Eakin and Marples (2001) concluded that replacing the estate tax with capital income tax will be likely to enhance economic efficiency by decreasing the deadweight loss of $\$ 0.018$ per dollar of wealth. Gale and Perozek (2001) examined the impact of estate taxes on saving. They found that it is impossible to pin down the effect of estate taxation on saving, because there is no consensus on the correct model of intergenerational transfers. Nevertheless, their analysis indicates that the widely-held presumption that estate taxes reduce saving is not a general result.

Finally, after reviewing the empirical and theoretical literature on the taxation of intergenerational transfers and wealth, Kopczuk (2012) concluded that theoretical work should further focus on understanding the implications of inequality of inherited wealth. On the other hand, potential negative externalities from wealth accumulation and concentration are yet to be seriously addressed.

This study adds to this field of research by using computer simulation to evaluate the efficiency effects of estate tax reforms in Taiwan. The purpose is to examine the effects of the proposed tax reforms on per capita consumption, capital accumulation, and excess burden (EB), holding the tax revenue constant, and to explore the optimal estate tax rate when there is no change in economy's capital stock. The paper is organized as follows. Section 2 describes the analytical model. Section 3 describes the tax reforms and parameter values chosen in the simulation. Section 4 reports on the simulation results. Section 5 summarizes the main points, draws conclusions, and describes important qualifications. 


\section{The Model}

The analytical model used for the simulation basically is a Ramsey-Cass-Koopmans (RCK) growth model (Ramsey, 1928; Cass, 1965; Koopmans, 1965) augmented by an estate tax structure, a household sector, and a competitive final output sector. Competition is used here because estate duty is not involved in commercial activities.

Most of the neoclassical growth models assume a fixed saving assumption. However, the dynamics of the saving rate path is rather elusive from a theoretical standpoint, and general statements on its properties are hard to obtain. Cass and Koopmans dropped the fixed savings assumption, allowing dynamic optimizing savings behavior in Ramsey model. The RCK model has become one of the most important theoretical frameworks in macroeconomics (Ramsey, 1928; Cass, 1965; Koopmans, 1965). The analytical model used for the simulation basically is an RCK growth model augmented by an estate tax structure, a household sector, and a competitive sector for final outputs. In this model, the household is assumed to behave like a representative agent, who can be viewed as a benevolent social planner. The planner makes optimal saving and consumption decisions over an infinite time horizon, given a utility of consumption and a fixed production technology. The RCK model is appropriate here to analyze the relationships between current consumption, saving decisions of agents, and future economic activity under the proposed estate tax structures.

\section{Household Consumption Decisions}

In the RCK model, the household is assumed to behave like a representative agent, who can be viewed as a benevolent social planner. The planner makes optimal saving and consumption decisions over an infinite time horizon, given a utility of consumption and a fixed production technology. The household sector includes equations describing the household budget constraint and preferences for consumption and saving. Considering a closed economy populated by $N$ identically and infinitely lived households growing at the exogenous rate $n$. The households maximize the discounted value of the utility of consumption $u(c(t))$ over an infinite horizon:

$$
U=\int_{0}^{\infty} e^{-\rho t} u(c(t)) d t
$$

where $\rho$ is the subject rate of time preference. Assuming that $u(c(t))$ is a function with constant inter-temporal elasticity of substitution $(\sigma), u(c(t))=\left[C(t)^{1-\sigma}-1\right] /(1-\sigma)$ and satisfies the Inada conditions, that is, $\lim _{c \rightarrow 0} u^{\prime}(c)=\infty$ and $\lim _{c \rightarrow \infty} u^{\prime}(c)=0$. The discounted value of the utility of consumption can be expressed as:

$$
U=\int_{0}^{\infty} \frac{c(t)^{1-\sigma}-1}{1-\sigma} e^{-\rho t} d t
$$

The household's total income per period is:

$$
Y(t)=\left\{\left(1-\tau^{P}\right)[w(t) N+r(t) K(t)]+\left(1-\tau^{L}\right) s(t) \bar{L}\right\}\left(1-\tau^{E}\right)
$$

where $w(t)$ is the wage rate, $K(t)$ is the total wealth, $\bar{L}$ is the land stock, $r(t)$ is the rate of return on capital, $s(t)$ is the unit rent paid to land. The household will choose the level of consumption and how much to save (bequest) under the present tax structure to maximize the present discounted value of the utility over an infinite horizon. To simplify notation, the index for time is dropped hereafter. The per capita household flow budget constraint is:

$$
\dot{k}=\left[\left(1-\tau^{P}\right)(w+r k)+\left(1-\tau^{L}\right) s \bar{l}\right] \cdot\left(1-\tau^{E}\right)-c-n k
$$


where $k$ is per capita capital stock, $\bar{l}$ is per capita land stock, $\tau^{P}$ is the proportional income tax rate, $\tau^{L}$ is the proportional land value tax rate, and $\tau^{E}$ is the proportional estate tax rate.

The present value Hamilton for the household's choice:

$$
M a x J=\frac{c^{1-\sigma}-1}{1-\sigma} e^{-\rho t}+v\left\{\left[\left(1-\tau^{P}\right) \cdot(w+r k)+\left(1-\tau^{L}\right) s \bar{l}\right] \cdot\left(1-\tau^{E}\right)-c-n k\right\}
$$

where $v$ is the present value of an additional unit of capital at time $t$. $v\left\{\left[\left(1-\tau^{P}\right) \cdot(w+r k)+\left(1-\tau^{L}\right) s \bar{l}\right] \cdot\left(1-\tau^{E}\right)-c-n k\right\}$ is the present value of the accumulative wealth. Setting derivatives of Equation (5) with respect to $c$ and $v$ equal to zero and taking the ratio of the two equalities gives the first order condition for consumption and the accumulation of wealth:

$$
\begin{gathered}
\frac{\partial J}{\partial c}=c^{-\sigma} e^{-\rho t}-v=0 \\
\frac{\partial J}{\partial v}=\left[\left(1-\tau^{P}\right) \cdot(w+r k)+\left(1-\tau^{L}\right) s \bar{l}\right] \cdot\left(1-\tau^{E}\right)-c-n k=\dot{k}=0
\end{gathered}
$$

Equation (6) represents household's optimal consumption choice, indicating that one unit of current consumption increase will reduce the accumulation of wealth, and therefore reduce the present value of capital stock. Assuming no Ponzi game allowed, that is:

$$
\lim _{t \rightarrow \infty}[v(t) \cdot k(t)]=0
$$

By using Euler equation, the costate equation of the Hamiltonian is:

$$
\frac{\partial J}{\partial k}=r v=-\dot{v}
$$

Using Equations (6) and (9) and the fact that consumption and production must grow at an equal rate in the long run, the growth rate for consumption is:

$$
\frac{\dot{c}}{c}=\frac{r-\rho}{\sigma}
$$

\section{Production of Final Output}

The final output is produced with a constant return to scale technology using physical capital, labor, and land as inputs. The technology is assumed to take the Cobb-Douglas form:

$$
Y=F(K, N, L)=A K^{\alpha} N^{B} L^{\gamma}, 0<\alpha, \beta, \gamma<1, \alpha+\beta+\gamma=1
$$

where $A$ is the rate of technological progress; $\alpha, \beta$, and $\gamma$ are positive fractions of inputs devoted to the production of final outputs. The final output sector, the labor market, and the physical capital market are perfectly competitive. Given the wage rate and the price of production inputs, final output producers choose how much labor and production inputs to employ. The optimal choices of the final outputs sector are shown by Equations (12), (13), and (14): 


$$
\begin{gathered}
r=\alpha A k^{\alpha-1} \bar{l}^{\gamma} \\
w=\beta A k^{\alpha} \bar{l}^{\gamma} \\
s=\gamma A k^{\alpha} \bar{l}^{\gamma-1}
\end{gathered}
$$

\section{The Government Sector}

The government finances public expenditure using taxation on household wages, interest and rent incomes, and bequests. Assuming that the government runs a balanced budget, the government's flow budget constraint is:

$$
T R=(w+r k) \cdot \tau^{p}+s \bar{l} \cdot \tau^{L}+\left[\left(1-\tau^{P}\right)(w+r k)+\left(1-\tau^{L}\right) s \bar{l}\right] \cdot \tau^{E}
$$

where TR is tax revenue, $(w+r k) \cdot \tau^{p}$ is revenue from household income, $s \bar{l} \cdot \tau^{L}$ is revenue from land value, and $\left[\left(1-\tau^{P}\right)(w+r k)+\left(1-\tau^{L}\right) s \bar{l}\right] \cdot \tau^{E}$ is revenue from bequests.

\section{Computer Simulations and Estate Tax Reforms}

This paper studies the efficiency effects of reducing estate tax rate and explores the optimal estate tax rate suitable for Taiwan. The idea is to examine how per capita consumption and capital differ when one tax rate is replaced with another. Meanwhile, this paper examines the EB of the reforms. A number of reforms designed to reduce estate tax rate have been proposed, including reducing the tax rate to zero (i.e., rescind the estate tax). To make quantitative analysis tractable, income tax rates remain unchanged, and a considerable amount of detail of actual tax system is excluded because it has no bearing on the issues studied here. The four reforms on estate tax are given as follows: (1) levied at a flat rate of $40 \%$; (2) levied at a flat rate of $10 \%$; (3) levied at a flat rate of $0 \%$ (i.e., rescind the estate tax); and (4) explore the optimal estate tax rate when holding physical capital constant.

Mathematica software is used to solve the model. The solution of the model requires numerical values for 12 parameters. In simulation, the parameters of the model are given the following values: $\rho=0.034,1 / \sigma=0.317$, $\tau^{P}=0.4, \tau^{L}=0.055, \tau^{E}=0.5, \alpha=0.37, \beta=0.60, \gamma=0.03, \quad \bar{l}=0.11134, \dot{c} / c=3.14 \%, n=3.58 \%, A=1.42 \%$.

\section{Simulation Results}

The model used here calculates the long-run effects of estate tax reforms. The simulated effects in estate tax rates, growth rate for per capita consumption, growth rate for per capita capital, and EB are shown in Table 1.

Reform 1 declines estate tax rate to $40 \%$ (the pre-reform tax rate was $50 \%$ ). Since government tax revenue is constant, the decline in estate tax rate has no income effect. The changes in welfare reported below result from substitution effects only, so they represent changes in the EB of the tax system. As Stiglitz (1978) showed that, because of the capital accumulation effects, Reform 1 has a tendency towards increased physical capital stock and decreased personal consumption. As the magnitude of the estate tax rate cut is not large, it may only slightly affect savings, thus slightly increasing the long-term capital stock. The last column in Table 1 indicates EB increases by an amount equivalent to $0.03 \%$ of real consumption. 
In Reform 2 as estate tax rate declines to $10 \%$, consumption demands decrease $2.20 \%$ and capital accumulations decrease $1.52 \%$. Intuitively, a large amount of estate tax cut leads to a reduction in savings which will tend to reduce the capital accumulation, and decreases the consumption demands in the long run. The EB also increases to $0.44 \%$ which was represented by the reduction of real consumption.

Table 1

Effects of Estate Tax Reforms

\begin{tabular}{lllll}
\hline Tax reform & Post-reform tax rates & $\Delta \dot{c} / c$ & $\Delta \dot{k} / k$ & $\Delta \mathrm{EB}$ \\
\hline $\begin{array}{l}\text { Reform 1 } \\
\text { Reduce tax rate }\end{array}$ & $\tau^{E}=40 \%$ & $-0.61 \%$ & $0.29 \%$ & $0.03 \%$ \\
\hline $\begin{array}{l}\text { Reform 2 } \\
\text { Reduce tax rate }\end{array}$ & $\tau^{E}=10 \%$ & $-2.20 \%$ & $-1.52 \%$ & $0.44 \%$ \\
\hline $\begin{array}{l}\text { Reform 3 } \\
\text { Repeal estate tax }\end{array}$ & $\tau^{E}=0 \%$ & $-2.64 \%$ & $-2.78 \%$ & $0.66 \%$ \\
\hline $\begin{array}{l}\text { Reform 4: } \\
\begin{array}{l}\text { (1) Change tax rate } \\
\text { (2) Keep capital stock constant }\end{array}\end{array}$ & $\tau^{E}=28.22 \%$ & $-1.28 \%$ & $0.00 \%$ & $0.14 \%$ \\
\hline
\end{tabular}

Notes. $\Delta$ indicates percentage change; $\dot{c} / c$ is changing rate of per capita consumption; $\dot{k} / k$ is changing rate of per capita physical capital; EB is excess burden of the tax system; $\tau^{E}$ is estate tax rate; the original tax rate is $\tau^{E}=50 \%$.

Reform 3 removes the estate tax duty from all inherited property. Simulation effects show that consumption demand and capital accumulation all have a dramatic decrease compared to Reforms 1 and 2 . In Reform 3, consumption demand decreases $2.64 \%$ and physical capital accumulation decreases $2.78 \%$. It is obvious that the abolition of estate tax without providing a complementary solution distorts household's consumption decisions and leads to an increase of EB by $0.66 \%$.

Reform 4 adjusts the estate tax rate while keeping economy's physical capital stock unchanged. Simulation result indicates that the optimum estate rate for Taiwan to keep capital stock constant is $28.22 \%$. Consumption demand decreases $1.28 \%$ and EB increases $0.14 \%$.

Based on the simulation results, a slight cut on estate tax rate will increase capital accumulation, conducive to economic growth, improve the efficiency of resources allocation, and lead to a less increase in EB of the tax reform, even though the decline of estate tax rate makes the consumption demand decrease. It is interesting to note that a significant decline of estate tax rate or even rescinding the estate tax will result in a decrease of capital accumulation. The result falls in line with the life cycle hypothesis and bequests effect. In sum, for the estate tax reform in Taiwan, a slight decrease on estate tax rate reform is proposed, and the decline of estate tax rate should not be lower than $28.22 \%$.

\section{Conclusions}

Taiwan's estate taxes are levied for the purpose of redistributing wealth. However, the fairness and reasonableness of estate taxes have long been disputed. After more than 10 years of practice, Taiwan's estate tax is no longer suitable for the needs of today's economic environment. In order to improve economic efficiency, starting from 2009, the Ministry of Finance of Taiwan has introduced a uniform tax rate of $10 \%$ to replace the original progressive tax rates. It is believed that this revision will help to reduce tax evasion, in favor of capital accumulation and enhance capital efficiency, while improving the degree of tax compliance, and thus implement fair taxation. 
Based on our simulation, the policy of repealing estate tax should not be conducted in Taiwan, since the abolition of estate tax will deteriorate economic efficiency and leads to the increase of welfare loss. Moreover, the simulation indicates that decreasing the estate tax rate from the original $50 \%$ to no less than $28.22 \%$ is optimal for Taiwan.

The implication of our simulation results is that Taiwan's current estate tax rate cut to $10 \%$ will not be able to increase capital stock and promote economic growth. Therefore, the Government should invest efforts in seeking alternative complementary measures and programs as sources for funding in order to maintain the principle of tax neutrality and to allow the nation's tax rate to conform to its overall environment.

\section{References}

Astrachan, J. H., \& Tutterow, R. (1996). The effect of estate taxes on family business: Survey results. Family Business Review, 9(3), 303-314.

Bernheim, D. (1987). Ricardian equivalence: An evaluation of theory and evidence. NBER Macroeconomics Annual, $2,263-304$.

Cass, D. (1965). Optimal growth in an aggregate model of capital accumulation. Review of Economic Studies, 32(3), 233-240.

Foster, J. D., \& Fleenor, P. (1994). An analysis of the disincentive effect of the estate tax on entrepreneurship. Tax Foundation Background Paper No. 9. Washington, DC: Tax Foundation.

Gale, W. G., \& Perozek, M. G. (2001). Do estate taxes reduce saving? In W. G. Gale, J. Hines, \& J. Slemord (Eds.), Rethinking estate and gift taxation (Chapter 5). Washington, DC: Brooking Institution Press.

Holtz-Eakin, D., \& Marples, D. (2001). Distortion costs of taxing wealth accumulation: Income versus estate taxes. NBER Working Paper, No. 8261.

Koopmans, T. (1965). On the concepts of optimal economic growth. In The econometric approach to development planning (pp. 225-287). Amsterdam: North Holland.

Kopczuk, W. (2012). Taxation of intergenerational transfers and wealth. NBER Working Paper, No. 18584.

Kotlikoff, L. J., \& Summers, L. H. (1981). The role of intergenerational transfers in aggregate capital accumulation. Journal of Political Economy, 89(4), 706-732.

Laitner, J. (2001). Inequality and wealth accumulation: Eliminating the federal gift and estate tax. In W. G. Gale, J. Hines, \& J. Slemord (Eds.), Rethinking estate and gift taxation (Chapter 6). Washington, DC: Brooking Institution Press.

Munnell, A. H., \& Ernsberger, C. N. (1988). Wealth transfer taxation: The relative role for estate and income taxes. New England Economic Review, November, 3-28.

Poterba, J. M., \& Weisbenner, S. J. (2001). The distributional burden of taxing estate and unrealized capital gains at the time of death. NBER Working Paper, No. 7811.

Ramsey, F. P. (1928). A mathematical theory of saving. Economic Journal, 38(152), 543-559.

Stiglitz, J. E. (1978). Notes on estate taxes, redistribution, and the concept of balanced growth path incidence. Journal of Political Economy, 86(2), 137-150.

Wagner, R. (1993). Federal transfer taxation: A study in social cost. Costa Mesa, CA: The Center for the Study of Taxation. 